\title{
PRE-SERVICE TEACHERS' PRIOR EXPECTATIONS AND THEIR ACTUAL EXPERIENCES OF TEACHING MATHEMATICS DURING PEDAGOGICAL INTERNSHIP IN ZIMBABWE
}

\author{
Chipo Makamure \\ University of South Africa, Republic of South Africa \\ E-mail: makamc@unisa.ac.za
}

\begin{abstract}
Pedagogical internship (PI) is an important component of teacher training programmes in Zimbabwe. It is envisaged to give student teachers experience in the classroom. However, the variation between the theoretical expectations of pre-service teachers (PST) and their actual experiences in the field has been a relational lacuna in academic research in Zimbabwe. This research sought to address this by presenting data on the relation between college PSTs' expectations about teaching mathematics and their actual experiences during PI in Zimbabwe. The study shares findings from a mixed methods study that employed two questionnaires completed by 120 PST before and during PI respectively, and a third questionnaire administered to school-based mentors. The researcher also conducted in-depth interviews with a few selected PSTS and teacher educators to elicit their views about the PSTs' practices. The results show that there is, indeed, a conflictual relationship between the PSTs' expectations of teaching mathematics and their experiences in the classroom. PSTs showed a consistent anticipation that they would sail through PI without many difficulties, but this expectancy turned out to be idealistic and impractical. The research also established that PSTs' expectations about teaching mathematics prior to PI can influence their field practices, hence, determining their opportunities to learn to teach the subject. It is recommended that teacher training institutions organize programmes for PSTs before PI to prepare and acquaint them fully with the skills that are needed to face challenges of teaching that may otherwise come as a shock during PI.
\end{abstract}

Keywords: expectations of teaching, field experiences, mathematics knowledge, pedagogical internship (PI), pre-service teachers (PSTS)

\section{Introduction}

Several studies, including that of Chong and Low (2009, p.61) and Delamarter (2015, p.2), have suggested that PSTs enter education programmes with pre-determined perceptions, expectations, and conceptions about teaching. According to Frydaki and Mamoura (2011), most PSTs view teaching from the way they interpret events and then perform according to how they comprehend it. This is due to the lenses of their beliefs and expectations. The tendency of viewing teaching knowledge this way implies that the expectations that PSTs bring to the classroom regarding mathematics teaching may influence their practice of teaching the subject. For example, PSTs with the belief that knowledge is certain and unchanging are likely to teach learners mathematics by mere transmission of what they know (Makamure, 2016). Du Toit Brits and $\mathrm{Nel}$ (2016, p. 81) therefore posited that teachers sometimes express expectations and, on these expectations, they behave in a specific manner. This idea is echoed by Incecay (2011), and Lo and Anderson (2010) who asserted that beliefs and expectations govern PSTs' thoughts, perceptions, actions, and judgements during field placement. 
Chipo MAKAMURE. Pre-service teachers' prior expectations and their actual experiences of teaching mathematics during pedagogical internship in Zimbabwe

PROBLEMS

OF EDUCATION IN THE $21^{\text {st }}$ CENTURY Vol. 78, No. 6,2020

984

In this research, a belief is considered as something one has surmised as true and expectations are regarded as predictions of what will happen. Beliefs can therefore influence expectations. For example, if a teacher believes mathematics is a difficult subject, that may affect his expectations about how it is taught. Purnomo et al. (2016) ascertained that beliefs that teachers have about the nature of mathematics determine instructional practices. This view is reflected in Peressini et al.'s (2004) study which submitted that some PSTs believe doing mathematics denotes getting correct answers fast and learning mathematics signifies mastering procedures. This belief of the nature of mathematics may prompt PSTs to encourage memorisation of concepts, formulae, and procedures in their teaching. The beliefs and expectations of PSTs can thus shape the PSTs' teaching behaviour which, in turn, can affect their opportunities to learn to teach mathematics during PI. There is therefore a connection between learning to teach and PSTs' expectations. If people learn by trying to make sense of the differences between their predictions (expectations) and reality, then the presence or absence of practice shock could affect opportunities to learn. For example, if PSTs think that the only thing they need to learn or teach during PI is content, then that also affects what they may be ready to learn. Hence the idea of expectations and reality impacts on the way of learning to teach.

There is a general consensus between Sag (2014) and Hamaidi et al. (2014) that PSTs' expectations of teaching are sometimes absolutely divorced from reality during PI. These discrepancies between PSTs expectations and reality have been documented differently by various scholars. Delamarter (2015), for example, contended in a case study that PSTs' expectations are often unrealistic. According to Delamarter, the expectations become unrealistic because most PSTs often generate an ideal in which they anticipate relational connections with the learners to trump content delivery. Whilst personal contact with learners is a crucial aspect of teaching, Delamarter professed that the PSTs tend to focus more on these relationships to the exclusion of academic considerations. Using observations, Eisenhardt et al. (2012) also argued that PSTs experience dissonance because their preconceived notions about learners conflict with their field experiences. The scholars argued that many classrooms today have become diverse and PSTs are not prepared to address the needs of diverse learners. This view shows that PSTs may miscalculate the abilities of their students and their own (PSTs) proficiency to teach some mathematical concepts. These miscalculations could result in reality shock if the PSTs' expectations fail to conform to their classroom practices. Delamarter $(2015$, p.2) consequently submitted that the sudden confrontation with the realities of PI may lead to practice shock for PSTs. Practice shock can be viewed as a sudden and surprising experience during PI when the PSTs' expectations about teaching conflict with the full realities of the classroom. According to Stokking et al. (2003), PSTs experience a shock when they struggle coping with change. However, Stokking et al. (2003) posited that the level of such challenges depends on the instruction they acquired in college and the support they are given during PI. These views illustrate that a thorough preparation of PSTs before PI may assuage the negative effects of PI surprises.

\section{Research Problem}

Considering the background stipulated above, the question that remains is: In what context is this problem of practice shock more pronounced and does the problem exist in the contexts of developing countries such as Zimbabwe? If so, in what forms and to what extent? According to Du Toit-Brits and Nel (2016), research into this phenomenon of PSTs expectations and experiences in developing countries such as South Africa is limited. Extensive research concerning teachers' expectations and teaching behaviour was in most cases conducted in the context of developed countries such as Canada and Israel (Du Toit-Brits \& Nel, 2016). In addition, research on the discrepancies between PSTs' expectations prior to and realities during PI have 
been well-documented in the developed countries by scholars such as Cole and Knowles (1993) who talked about shattered images of PSTs. In other studies, Pourdavood (2017) explained PSTs' expectations towards mathematics while Sheridan (2016) examined changes in PSTs' beliefs of pedagogy. Furthermore, Purnomo et al. (2016) outlined PSTs' beliefs and practices in mathematics classes whereas Weinstein (1988) described unrealistic optimism. More work is therefore required for developing country contexts because PSTs in these countries, including Zimbabwe, have disparate cultural environments and varied exposures compared to the rest of the developed countries. Zimbabwe differs from developed countries because of its status as an underdeveloped country. This gap therefore prompted the research to explore mathematics PSTs' expectations and their practices in Zimbabwe.

The present research presents the extent to which PSTs' expectations impact on their field practices in Zimbabwe. Furthermore, the research argues for the rationale to examine information on the ways in which the gap (if any) between PSTs' expectations of teaching mathematics before and their actual experiences during PI can be taken into account. This would reduce teaching challenges faced by PSTs and create better opportunities for them to learn to teach mathematics. Two research questions guided the research. The first is: How are Zimbabwean PSTs' expectations concerning teaching mathematics before PI and their actual practices during PI related? The second one is: To what extent do PSTs' expectations concerning teaching mathematics during their teacher education programme reflect in their actual classroom teaching practices?

\section{Research Focus}

Naylor et al. (2015) indicated that PSTs join teacher education programmes with a diversity of educational and life experiences, hence, diverse beliefs, values, and dispositions. Similarly, Feiman-Nemser (2001) affirmed that PSTs have lifelong experiences before teacher education. For this reason, the PSTs could have idiosyncratic preconceived ideas about teaching. These preconceived ideas may construct and give birth to various peculiar expectations among them as they step into teacher education programmes. Most PSTs may therefore want to relate their PI classes with their personal experiences. Briley (2012) and Yilmaz and Sahin (2011) agreed that PSTs' prior conceptions about teaching are linked directly to their classroom practices. Similarly, Naylor et al. (2015) affirmed that prior experiences and beliefs influence the skills and knowledge to be presented in the classroom. For example, if a PST was earlier on taught with a particular teaching method, their perspective on teaching may evolve around this method. This suggests that previous experiences may exacerbate the tendency to underestimate the complexity of teaching, which can give rise to unlimited and unhealthy surprises during PI. Using a survey, Kahn et al. (2014) also argued that beliefs (which are presumed to give birth to expectations) cannot be separated from classroom practices. The ideas adduced above suggest that class practices of PSTs are likely to be determined by prior expectations which emerge as a result of prior experiences.

\section{Expectations and Practice Shock}

Wall's (2016) study found that PSTs before PI expect and believe that teaching is simple and that teaching ensures learning, teaching is autonomous and that learners perform uniformly within grade levels. Such expectations may affect and determine the PSTs' teaching methodologies and their perception of the learners they teach. In contrast with their expectations, PSTs usually find themselves frustrated and bewildered owing to unprecedented factors that emerge from classroom contexts (Wall, 2016).

\author{
PROBLEMS \\ OF EDUCATION \\ IN THE $21^{\text {st }}$ CENTURY \\ Vol. 78, No. 6,2020 \\ 985
}


Chipo MAKAMURE. Pre-service teachers' prior expectations and their actual experiences of teaching mathematics during pedagogical internship in Zimbabwe

PROBLEMS

OF EDUCATION IN THE $21^{\text {st }}$ CENTURY Vol. 78, No. 6,2020

986

Weinstein (1988) raised the issue of "unrealistic optimism" among PSTs, which can culminate into practice shock. Weistein (1988) asserted that the structure and content of teacher education programmes can also contribute to unrealistic expectations among PSTs. In particular, Weinstein's study alluded to the programmes in teacher education as being deficient in typical characteristics of professional preparation. For example, Weinstein's study found that programmes in universities portray the notion that learning to teach is not problematic as long as certain procedures are followed religiously, hence averting discussions on what PSTs should do in the face of a challenge during PI. Wall (2016) concurred that there seems to be a mismatch between PSTs' learning on campus (which can give rise to expectations) and their practices in the field. This mismatch implies that the theoretical knowledge acquired by PSTs in college may not suffice in the implementation of skills in teaching.

Grouws et al. (1996) developed a theoretical framework with several categories for mathematical beliefs of teachers. One of the categories entails beliefs about the structure, composition, and status of mathematics (nature of mathematics). For instance, mathematics can be perceived by PSTs as a group of distinct, independent facts (Grouws et al., 1996). When PSTs carry this view into the classroom during PI, they may promote "instrumental understanding" of mathematical concepts among learners, whereby certain procedures are used to solve mathematical tasks without comprehension of why and how the procedures function (Leikin \& Levav-Waynberg, 2009). An understanding of what mathematics is and better forms of teaching it by PSTs prior to PI may redirect their expectations about teaching mathematics during PI. Pourdavood (2017) asserted that views about what mathematics is and what it is not influence PSTs' expectations, experiences, and beliefs towards teaching mathematics.

In one study on PSTs' expectations regarding teaching mathematics before PI, Lo and Anderson (2010) revealed that some PSTs regard mathematics as a constant body of knowledge. This view suggests that PSTs are just there to re-teach mathematics for content retention and not for understanding and application of mathematical concepts. In the same vein, Peressini et al. (2004) submitted that PSTs believe that performing mathematics entails obtaining correct answers at the drop of a hat and that mastering procedures and memorising rules signify learning mathematics. For this reason, McDiarmid and Ball (1998) affirmed that PSTs assume that "good" mathematics learners are students who can recall formulas and procedures and, as a result, the inability to memorise these formulae and procedures implies poor performance. Such a mind-set is likely to determine the PSTs' teaching strategies. When these strategies fail to work and the goals of teaching are not met, it may result in "unrealistic optimism" among PSTs, which can give rise to reality shock in the classroom. Some PSTs are confident to teach mathematics when they are on PI, assuming they are familiar with the subject content (Lee et al., 2013). What could be concealed to them is that the tacit comprehension of mathematics may not be helpful to the learner if it remains dormant. Whilst PSTs may think they have adequate pre-requisite ability to teach effectively because they have the content, they may fail to realise that content alone can lack the multi-dimensionality that makes the classroom a complex environment. Despite the knowledge of mathematics content, they have, PSTs are normally biased towards their ability to instruct learners from different cultures and to deal with individual differences in the classroom (Weinstein, 1988). Naylor et al. (2015) hence indicated that teacher education programmes have been sold short by the lack of internship, detachment of theory and practice, and transmissive teaching models taught in universities. These programmes in the universities are likely to impact on the PSTs' perceptions and expectations about teaching mathematics. For example, the programmes portray a situation where teaching mathematics may be viewed as being theoretical and remote and that it can be done by any educated person (Naylor et al., 2015). However, PSTs get shocked when the situation in the classroom immerses them in the "real, practical and immediate" teaching contexts (Naylor et al., 2015, p.120). The teacher education curriculum should therefore strive to make PSTs understand that teaching mathematics goes beyond subject content, theory or having a "bag of tricks" (Naylor et al., 2015, p.120) to teach it. 
Given that PSTs enter PI with extensive pre-conceptions about teaching, the role of teacher education is to challenge their preconceived knowledge of the subject that they will teach (Naylor et al., 2015). This role helps them to have a positive change regarding teaching and promotes "learning to teach" (Sheridan, 2016) particularly learning to teach mathematics. It is therefore vital for teacher educators to be aware of PSTs' prior expectations to improve the PSTs' practices, hence, fostering effective teaching and learning of mathematics. Prior expectations may be preserved if they are consistent with the demands of learning to teach (Peressini et al., 2004), but can be reshaped or rerouted if they are incompatible and misaligned with teaching (Barahona, 2014). Sometimes when PSTs notice that their expectations are dysfunctional, they panic and, ultimately, their dreams and hopes are shattered. These pre-existing expectations may be altered if teacher educators can present data which is believable, practical, convincing, and explainable to PSTs (Clark-Goff \& Eslami, 2016). White and Chant (2014) suggested that teacher educators (both in college and in schools) should create opportunities for PSTs to see the practical application of mathematics theory by challenging their expectations and perceptions. The implication of this idea is that teacher educators must be privy to the thoughts and expectations that are brought by PSTs to the classroom and be prepared to challenge and reinforce them so that change occurs. PI is therefore the domain in which expectations can be reinforced and/or challenged to create the opportunity to learn to teach mathematics.

\section{Research Methodology}

\section{General Background}

The present research was anchored on the pretext that mathematics is a practical subject and that it can only be understood through practice. The pragmatist philosophy was employed to guide the selection of the mixed methods approach to explore the connection between PSTs' theoretical expectations and their educational performance in the classroom with regard to mathematics teaching in Zimbabwe. The pragmatist paradigm is an ideology which believes that education must be practical and must occur through experience (Creswell, 2014). Since the research intends to establish the extent to which PSTs' expectations resonate with their field practices, it fits well into the precepts of pragmatism. The explanatory sequential design was deemed to be suitable for this research so that quantitative findings can be clarified and interpreted by qualitative data to ensure that the results are credible and trustworthy (Terrell, 2012). As this study employed the explanatory design, the researcher was able to distribute questionnaires to participants first before and during PI. This was followed by focus group interviews (FGI) during PI. This was done to evaluate the link between PSTs' previous expectations and beliefs against their field experiences. According to Ivankova (2014), the explanatory design allows confirmation by qualitative means (FGI) in the event that questionnaires provide unexpected data. During their first year, PSTs in Zimbabwe learn pedagogics of teaching mathematics as well as mathematics content. During their second year (on PI), they are deployed in schools all over the country (rural and urban areas) and the practising schools are diverse in terms of teaching and learning resources. In their final year ( $3^{\text {rd }}$ year), the PSTs continue with pedagogics and mathematics content up to first year degree level. A conscious decision regarding which PSTs would provide the desired information was therefore made. 
Chipo MAKAMURE. Pre-service teachers' prior expectations and their actual experiences of teaching mathematics during pedagogical internship in Zimbabwe

PROBLEMS

OF EDUCATION

IN THE $21^{\text {st }}$ CENTURY Vol. 78, No. 6, 2020

988
Sample

Convenience sampling was used to select 120 first year PSTs from two colleges using codes A and B. The figure was thought to be a realistic representation of the population of 160 as it represented $75 \%$ of the total number of first-year mathematics PSTs in the two colleges A and B. A population of 160 calculated at $95 \%$ confidence level and margin error of $4.5 \%$ would require a sample size of 120 . The researcher also purposively selected 42 school-based mentors from the 3 provinces where most students were deployed for PI. The mentors were selected from teachers who supervised the PSTs during PI. Seven college-based teacher educators also participated in the research.

\section{Instrument and Procedures}

First year mathematics PSTs from two teachers' colleges A and B were selected to answer a group-administered questionnaire (separately) prior to PI. This sought to determine their pre-conceptions and expectations of mathematics content, mathematics teaching and mathematics learners before field experiences. A follow-up questionnaire developed by the researcher was also administered to 105 PSTs in the middle of their PI. The PSTs were from the same group that responded to the initial questionnaire. This questionnaire was meant to solicit information on the PSTs' experiences during PI. The responses enabled the researcher to compare PSTs' expectations before PI with their actual experiences during PI. FGIs were also conducted with 22 PSTs from the same group that answered questionnaires to allow for in-depth exploration of the findings. The secondary teachers' colleges A and B were thus considered as they had first year PSTs in session and were soon expected to go on internship. The 42 mentors answered a questionnaire to elicit information illustrating any discrepancies in the perceptions of mentors about PSTs' practices during PI. Follow-up FGIs with 14 mentors who participated in answering questionnaires were also conducted to ascertain their views about the strengths and shortcomings of PSTs during PI. The questionnaire focused on their mathematics content knowledge and their teaching knowledge in the field. Selected college-based lecturers also answered individualised semi-structured interviews to establish their views concerning the nature of mathematics knowledge acquired by PSTs during their time in college.

\section{Data Analysis}

The first questionnaire developed by the researcher requested for PSTs' demographic data and teaching expectations, whilst the second one sought their teaching experiences. The third questionnaire sought mentors' views about PST's classroom performance. The SPSS programme was used to analyse responses to the three questionnaires and to test their reliability. The Cronbach's alpha coefficient was computed to give the coefficients $0.614,0.850$ and 0.758 for the three questionnaires, respectively. Although coefficients of over 0.7 are recommended for a strong approximation of reliability, coefficients under 0.7 may realistically be accepted, especially when working with psychological constructs such as personal traits, abilities and attitudes (Kline, 1999). This justifies the relatively low scale of 0.614. The three questionnaires' internal consistency were therefore relatively high. The quantitative data collected from questionnaires were cleaned, entered, and analysed using the SPSS programme. The results of the questionnaires were analysed on a 5-point Likert scale using descriptive statistics and paired samples $t$-test. The 5-point Likert scale was given a weighting of 1 to 5, and had the highest score of 5 representing 'Strongly Agree' (S.A), with 'Strongly Disagree' (S.D) taking the lowest score of 1 . Using the Likert scale enabled the calculation of means and standard deviations necessary in this mixed methods design study. The descriptive analysis reported 
Chipo MAKAMURE. Pre-service teachers' prior expectations and their actual experiences of teaching mathematics during pedagogical internship in Zimbabwe

PROBLEMS

OF EDUCATION

IN THE $21{ }^{\text {st }}$ CENTURY

Vol. 78 , No. 6,2020

on the frequencies, percentages, means and standard deviations of the PSTs' expectations and experiences during PI. A paired samples t-test analysis was carried out at $5 \%$ significance level to determine the significance of the difference between the two means of 'expectations' of teaching prior to PI and 'teaching experiences' in the field.

The result of the interviews with the lecturers, mentors, and PSTs were presented and analysed to confirm quantitative data. To ensure that the trustworthiness and credibility criteria is met, interview data were compared with the quantitative data, and audio recordings were transcribed into textual data.

\section{Research Results}

\section{Expectations and Experiences of Teaching}

Table 1 juxtaposes the means of expectations of teaching prior to PI and the experiences during PI on the question items that examined the same skills, so as to establish the discrepancies between the two constructs. Expectations were drawn from questionnaire 1 administered prior to PI, whilst the experiences were from questionnaire 2 answered by PSTs during PI.

\section{Table 1}

Expectations and Experiences of Pedagogical Internship Compared

\begin{tabular}{|c|c|c|c|c|c|c|c|}
\hline \multirow[b]{2}{*}{ Item } & \multicolumn{3}{|c|}{$\begin{array}{l}\text { Expectations of learning to teach before PI } \\
\text { (Extract from Questionnaire 1) }\end{array}$} & \multicolumn{4}{|c|}{$\begin{array}{l}\text { Classroom experiences during PI (Extract from } \\
\text { questionnaire 2) }\end{array}$} \\
\hline & Expectations & $M$ & $S D$ & Item & Experiences & $M$ & $S D$ \\
\hline 8 & $\begin{array}{l}\text { I know how to manage my } \\
\text { classroom during lessons }\end{array}$ & 3.91 & .773 & 9 & $\begin{array}{l}\text { My classroom management } \\
\text { skills are quite appropriate }\end{array}$ & 4.10 & .714 \\
\hline 9 & $\begin{array}{l}\text { I know how to deal with students' } \\
\text { misconceptions and understanding }\end{array}$ & 3.65 & .820 & 10 & $\begin{array}{l}\text { I have an understanding of how } \\
\text { students learn mathematics }\end{array}$ & 3.97 & .771 \\
\hline 10 & $\begin{array}{l}\text { I can adjust my teaching based on } \\
\text { students' understanding }\end{array}$ & 4.24 & .745 & 22 & $\begin{array}{l}\text { I can adjust my teaching styles } \\
\text { to suit various learners }\end{array}$ & 4.31 & .731 \\
\hline 11 & $\begin{array}{l}\text { I will be able to adjust my styles of } \\
\text { teaching to suit various learners }\end{array}$ & 4.37 & .750 & 22 & $\begin{array}{l}\text { I can adjust my teaching styles } \\
\text { to suit various learners }\end{array}$ & 4.31 & .731 \\
\hline 12 & $\begin{array}{l}\text { I can choose good teaching styles } \\
\text { to direct students' learning }\end{array}$ & 4.20 & .763 & 11 & $\begin{array}{l}\text { I can apply different teaching } \\
\text { approaches during lessons at } \\
\text { appropriate times }\end{array}$ & 4.21 & .762 \\
\hline 13 & $\begin{array}{l}\text { I can select appropriate teaching } \\
\text { resources to improve my teaching } \\
\text { strategies }\end{array}$ & 3.99 & .855 & 15 & $\begin{array}{l}\text { I can select appropriate teaching } \\
\text { resources that enhance my } \\
\text { teaching }\end{array}$ & 4.28 & .630 \\
\hline 14 & $\begin{array}{l}\text { Knowing different approaches } \\
\text { means the ability to use them }\end{array}$ & 3.59 & 1.061 & 13 & $\begin{array}{l}\text { I know about different } \\
\text { approaches which means I can } \\
\text { use them for teaching }\end{array}$ & 3.78 & 1.180 \\
\hline 15 & $\begin{array}{l}\text { A variety of approaches to teach a } \\
\text { concept confuses students }\end{array}$ & 2.66 & 1.297 & 12 & $\begin{array}{l}\text { Using a variety of approaches } \\
\text { may confuse students }\end{array}$ & 2.64 & 1.381 \\
\hline 16 & $\begin{array}{l}\text { I will be able to use skills gained in } \\
\text { college during } \mathrm{PI}\end{array}$ & 4.28 & .856 & 18 & $\begin{array}{l}\text { It is quite easy to utilise skills } \\
\text { gained in college during } \mathrm{PI}\end{array}$ & 3.62 & 1.021 \\
\hline 17 & $\begin{array}{l}\text { I am able to relate well with the } \\
\text { students during } \mathrm{PI}\end{array}$ & 4.11 & .768 & 20 & $\begin{array}{l}\text { There is a sound relationship } \\
\text { between me and my students }\end{array}$ & 4.30 & .786 \\
\hline 18 & $\begin{array}{l}\text { The teacher should accept students' } \\
\text { ideas and propositions }\end{array}$ & 4.20 & .826 & 24 & $\begin{array}{l}\text { I respect and accept students' } \\
\text { thoughts and suggestions }\end{array}$ & 4.41 & .661 \\
\hline
\end{tabular}


Chipo MAKAMURE. Pre-service teachers' prior expectations and their actual experiences of teaching mathematics during

pedagogical internship in Zimbabwe

PROBLEMS

OF EDUCATION

IN THE $21^{\text {st }}$ CENTURY Vol. 78, No. 6,2020

990

\begin{tabular}{llllllll}
\hline & $\begin{array}{l}\text { Expectations of learning to teach before PI } \\
\text { (Extract from Questionnaire 1) }\end{array}$ & \multicolumn{4}{l}{$\begin{array}{l}\text { Classroom experiences during PI (Extract from } \\
\text { questionnaire 2) }\end{array}$} \\
\hline Item & Expectations & $M$ & $S D$ & Item & Experiences & $M$ & $S D$ \\
\hline $\begin{array}{l}\text { I can motivate students lacking the } \\
\text { desire to learn maths }\end{array}$ & 4.33 & .650 & 19 & $\begin{array}{l}\text { I can motivate students who lack } \\
\text { the desire to do mathematics }\end{array}$ & 4.24 & .779 \\
\hline & $\begin{array}{l}\text { I can assess students' learning in } \\
\text { various ways }\end{array}$ & 3.90 & .827 & 26 & $\begin{array}{l}\text { I can assess and evaluate my } \\
\text { students' performance in the } \\
\text { classroom }\end{array}$ & 4.34 & .782 \\
20 & $\begin{array}{l}\text { Teaching is what I expected in life } \\
21\end{array}$ & 3.18 & 1.275 & 29 & $\begin{array}{l}\text { Teaching is what l expected } \\
\text { in life }\end{array}$ & 3.48 & 1.356 \\
\hline & Expectations (Total average) & 3.90 & .876 & Experiences & 3.99 & .889 \\
\hline
\end{tabular}

*Note: Each pair of items from Q1 and Q2 is testing the same skill. $M$ - Mean, $S D$ - Standard Deviation

From Table 1, the PSTs evaluated themselves quite high in terms of teaching before and during PI as indicated by the total means of 3.9 and 3.99, respectively. The result indicates that an overwhelming majority of the PSTs were confident of being able to teach well and present lessons with minimal problems as shown by the means of the responses from the first questionnaire ranging from 3.91 to 4.37 . This demonstrates a strong agreement. This result is supported by the $t$-test analysis that was done to determine the significance of the difference between expectations of teaching prior to PI and classroom experiences during PI. This is illustrated in the results below:

Table 2

Testing the Difference between Expectations and Experiences

\begin{tabular}{lllll}
\hline$\mu$ & Paired Differences & $t$ & $d f$ & $p$ \\
& $\mu$ & $S D$ & & \\
\hline
\end{tabular}

\begin{tabular}{|c|c|c|c|c|c|c|}
\hline Pair 1 & $\begin{array}{l}\text { Expectations of learning to } \\
\text { teach before pedagogical } \\
\text { internship - classroom } \\
\text { experiences during } \\
\text { pedagogical internship }\end{array}$ & -.09857 & .26878 & -1.372 & 13 & .193 \\
\hline
\end{tabular}

In Table $2, \mu_{\mathrm{D}}$ is the difference between means of expectations before PI and classroom experiences in the field. Since, we do not reject $\mathrm{H}_{0}$ and conclude that, there is inadequate evidence to claim that at 5\% level of significance, expectations of teaching before PI are different from experiences during PI. The result therefore explains that PSTs' expectations of teaching were associated to their experiences during PI.

The expectations and experiences in Table 1 above are however grouped into instructional and relational practices. In this research, relational expectations refer to expectations of academic relationship or association between the teacher and their students. This includes provision of social-emotional learning needs to the student by the teacher. Instructional expectations and experiences are considered in the research as practices regarding the actual teaching processes that include the teaching of mathematics content and the styles of teaching it for understanding. The instructional practices in table 1, which are the main focus of the research, show that there are negative differences between expectations and experiences during PI. This implies that teaching expectation levels were higher than the experience levels, hence, expectations were not met. The instructional practices have been extracted from table 1 to be reflected in Table 3 below: 
Chipo MAKAMURE. Pre-service teachers' prior expectations and their actual experiences of teaching mathematics during pedagogical internship in Zimbabwe

Table 3

Instructional Expectations and Experiences of PI Compared

\begin{tabular}{|c|c|c|c|c|c|}
\hline Q1 & Q 2 & Comparison & of Expectation & and Experiences & \\
\hline Item No. & $\begin{array}{l}\text { Item } \\
\text { N0. }\end{array}$ & ITEMS & $\begin{array}{l}\text { Expectations } \\
M \text { (E1) }\end{array}$ & $\begin{array}{l}\text { Experiences } \\
M(E 2)\end{array}$ & $\begin{array}{l}\text { Difference Between } \\
\text { Expectations and } \\
\text { Experiences } \\
\text { (E2 - E1) }\end{array}$ \\
\hline 11 & 22 & $\begin{array}{l}\text { I will be able to adjust my styles of } \\
\text { teaching to suit various learners }\end{array}$ & 4.37 & 4.31 & -0.06 \\
\hline 15 & 12 & $\begin{array}{l}\text { A variety of approaches to teach a } \\
\text { concept confuses students }\end{array}$ & 2.66 & 2.64 & -0.02 \\
\hline 16 & 18 & $\begin{array}{l}\text { It is quite easy to utilise skills gained } \\
\text { in college during PI }\end{array}$ & 4.28 & 3.62 & -0.66 \\
\hline 19 & 19 & $\begin{array}{l}\text { I can motivate students lacking the } \\
\text { desire to learn maths }\end{array}$ & 4.33 & 4.24 & -0.09 \\
\hline
\end{tabular}

*Notes: Q1 means Questionnaire 1 before PI; Q2 means Questionnaire 2 during PI; A pair of items in Q1 and Q2 tests the same skill

Generally, Table 3 shows that PSTs were over expectant in instructional practices of teaching mathematics rather than in relations with learners. However, PSTs' responses to item 16 before PI $(M=4.28)$ and item 18 during PI $(M=3.62)$, were disparate. Items 16 and 18 read: "It is quite easy to utilise skills gained in college during PI". The PSTs' responses concerning their ability to use college acquired skills in the classroom were therefore obtrusively different and the rating decreased from $89.8 \%$ to $61.1 \%$, as depicted in Figure 1 below.

\section{Figure 1}

It is Easy to Utilise the Skills Gained in College during PI

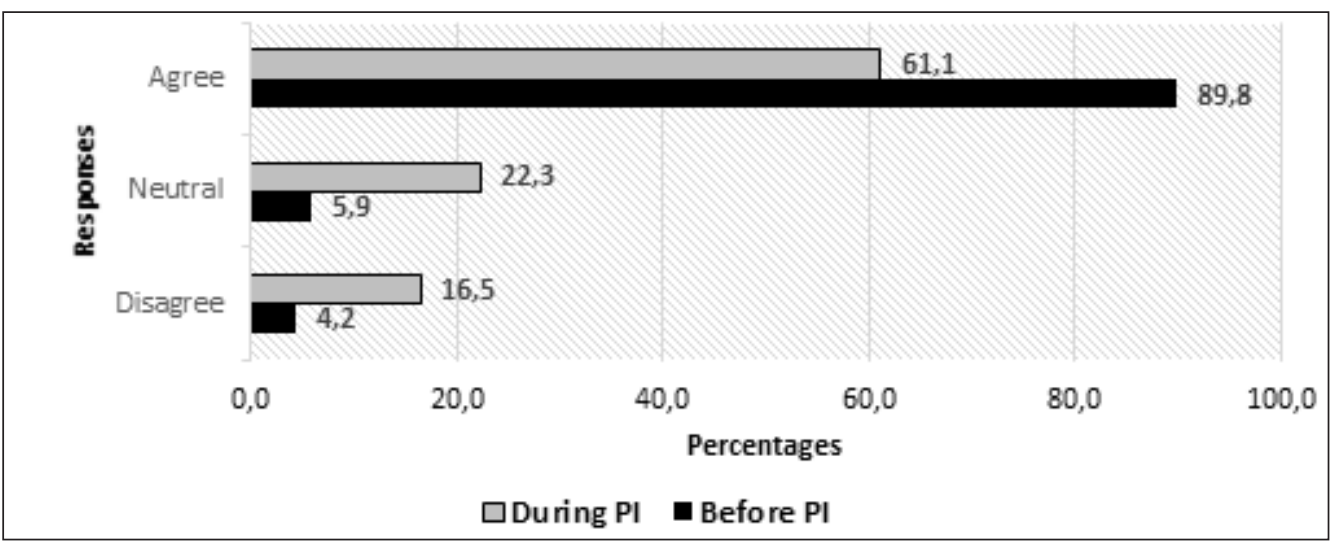

The PSTs' reflections show that they expected application of skills to be easy and lessons conducted according to the way the PSTs were prepared in college as evidenced by the high score of $89.8 \%$. These expectations suggest that PSTs enter the teaching profession with somewhat many expectations regarding teaching and learning. The difference between $89.8 \%$ and $61.1 \%$ may also indicate that the PSTs may have underestimated learners' learning needs and over anticipated their own (PSTs) capability to implement the skills learned in the classroom setting prior to PI. For example, the teaching approaches that the PSTs used during PI could have been unsuitable for the quantity of work they planned, the topics they taught and learners' aptitudes. 
Chipo MAKAMURE. Pre-service teachers' prior expectations and their actual experiences of teaching mathematics during pedagogical internship in Zimbabwe

PROBLEMS

OF EDUCATION

IN THE $21^{\text {st }}$ CENTURY Vol. 78, No. 6,2020

992

The following selected reflections from participant A6 during interviews (which were echoed by other participants) indicate PSTs' lived experiences on this matter.

My view was that pupils' understanding would be better. However, the reality in the classroom revealed to me that, for each topic, although I thought it was easy, when they wrote the individual work, they would give different answers on the same question. I expected them to perform the same... so, yeah, it's not that easy. You don't know how to teach them in order to understand.

Although the above pre-service teacher expected teaching to be easy, probably because she knew the content, the following interview response from A5 shows that media selection, contrary to the PSTs' expectations, was very demanding.

...Or else you go with a chart, you think they will quickly understand what is on the chart, then you realise sometimes you need concrete things like when you choose media. Say, I am doing area, I say, side by side. Sometimes you need to go with something like a tile, then you show them that, this is the dimension, and this is another dimension, instead of just doing charts.

From these responses, A6 was concerned about the most effective methods for use to teach students with varied abilities. A5 also realised immediately the significance of using concrete objects to improve understanding of concepts, showing that education can come through experience. Many PSTs seemed to have a myriad of teaching strategies but still required to catch up with the details of how and when to implement them during classroom teaching. The PSTs' expectations regarding what would be required seemed to conflict with reality. The findings show that PSTs regard PI as easy to achieve, but they become discouraged when their theoretical expectations are confronted by practical reality.

Over $70 \%$ of participants expected teaching mathematics to be simple and straightforward, which turned out to be unrealistic. This finding confirms the quantitative results from questionnaire two (Table 4 ) which indicate that $70.6 \%$ of the PSTs were disagreeable to or unsure about the match between their expectations and experiences of teaching.

Data from item 30 of questionnaire 2 (Table 4) describe PSTs as less positive concerning the relationship between their expectations and classroom experiences. This is demonstrated by the low mean of 2.54 and a low measure of $29.4 \%$ agreement. The standard deviation is $0.857<1.0$, which implies that responses are homogeneous as shown in Table 4 below.

\section{Table 4}

Pre-service Teachers' Expectations vs Experiences

\begin{tabular}{llllllll}
\hline & $N$ & Disagree & Neutral & Agree & \\
\hline Experiences during pedagogical internship & & & & & M & SD \\
\hline 30. & $\begin{array}{l}\text { My classroom expectations of teaching } \\
\text { mathematics before pedagogical internship } \\
\text { match my experiences during pedagogical } \\
\text { internship }\end{array}$ & 104 & $58 \%$ & $12.6 \%$ & $29.4 \%$ & 2.54 & 0.857 \\
& & & & & & \\
\hline
\end{tabular}

*Note: The mean column stands for the mean on the Likert scale $(1-5)$

The results of Table 4, Figure 1 and the PSTs' interviews show that, during PI, the PSTs in this research, in contrast with their expectations, faced multiple challenges. These included problems that were associated with growing their teaching techniques during lessons and lesson preparations.

$$
\text { Mentors 'views on PSTs' Practices during PI (extract from questionnaire 3) }
$$


Chipo MAKAMURE. Pre-service teachers' prior expectations and their actual experiences of teaching mathematics during pedagogical internship in Zimbabwe

Table 5 below shows the views of school-based mentors about PSTs classroom practices.

\section{Table 5}

Mentors' Views about PSTs' Classroom Practices (Questionnaire 3)

\begin{tabular}{llllllll}
\hline & $\begin{array}{l}\text { ITEM } \\
n=42\end{array}$ & $n$ & Disagree & Neutral & Agree & $\boldsymbol{M}$ & SD \\
\hline $\begin{array}{l}\text { The college has done enough to prepare pre- } \\
16\end{array}$ & 40 & $55 \%$ & $12.5 \%$ & $32.5 \%$ & 2.88 & 0.791 \\
\hline $17 \quad$ service teachers for pedagogical internship & My mentee knows the content s/he teaches & 40 & $7.5 \%$ & $17.5 \%$ & $75 \%$ & 3.88 & 0.911 \\
\hline $18 \quad \begin{array}{l}\text { My mentee's classroom management is very } \\
\text { satisfactory }\end{array}$ & 39 & $10.3 \%$ & $17.9 \%$ & $71.8 \%$ & 3.67 & 0.838 \\
\hline $19 \quad \begin{array}{l}\text { Field experience courses offered in teachers' } \\
\text { colleges for mathematics pre-service teachers } \\
\text { need to be enhanced }\end{array}$ & 40 & $2.5 \%$ & $17.5 \%$ & $80 \%$ & 3.95 & 0.677 \\
\hline
\end{tabular}

*Note: The mean column stands for the mean on the Likert scale

The responses for items 16, 17 and 19 of questionnaire 3 suggest that, although PSTs have the subject content (item 17), they may still be struggling with pedagogy (items 16, 19). The mentors hence suggested that internship courses offered in teachers' colleges need to be improved (item 19, mean =3.95) so as to enhance the PSTs' performance.

In their explanation of the problems they faced with PSTs on PI (Questionnaire 3), the main issues raised by the school-based mentors included PSTs resisting advice (25\%), and poor teaching styles (11.1\%), among others. These assertions were substantiated by the outcomes of the interviews carried out with some school-based mentors who had this to say about their mentees:

M13: .... there are some students who want to show you that they know so much that, when you want to assist them, they will tell you they know, know the mark to give. Some do not attend lessons......

The reflections above are evidence of an "I know it all" attitude from the PSTs, which could have emanated from their predictions about teaching. These views are likely to deprive the PSTs of the opportunities to learn "how to teach". The mentors also indicated that some PSTs lacked confidence in teaching senior classes. PSTs' reluctance to teach senior classes could be confirmation of a lack of both content and the pedagogical knowledge. In the interviews with college educators, they refuted the idea that colleges encouraged schools to allocate PSTs junior classes only. The school-based mentors also attributed the PSTs' shallow pedagogical knowledge to the training acquired in college (Table 5). They suggested that what the PSTs are learning in colleges is possibly not related to what they are supposed to teach in schools. This gap could give PSTs false expectations (unrealistic optimism) and little confidence to teach examinations classes. This is because PSTs lacked subject content. Mentor (M6) exhibited his sentiments about this matter as follows:

M6: ....... these student teachers have no confidence. What they are taught at college has no link with what they teach here. Because they are doing "integration" there, they come here they want to 
Chipo MAKAMURE. Pre-service teachers' prior expectations and their actual experiences of teaching mathematics during pedagogical internship in Zimbabwe

PROBLEMS

OF EDUCATION

IN THE $21^{\text {st }}$ CENTURY Vol. 78, No. 6,2020

994

teach "transformations". ....... What I am saying is, lecturers should check: Is he able to articulate, to transfer what is in his mind to the students? Does he understand how students learn themselves?

According to the school curriculum in Zimbabwe, the topic "integration" is taught at "Advanced" level and "transformations" is taught at "Ordinary" level. When these students go on PI, they are expected to teach up to "O" level. The one point that mentors seem to be foregrounding in the above statement is the need for mathematics taught in colleges to link directly with the content that PSTs are expected to teach in schools. The connection means that the college syllabus should include ' $\mathrm{O}$ ' level 'topics such as "transformations". Going through the ' $\mathrm{O}$ ' level topics in college could regenerate their confidence in the classroom. In responding to the question item that needed college lecturers to validate whether college mathematics courses were sufficient to prepare PSTs for PI, the discussions with some educators were as follows:

Lecturer 4: $\quad$ I think, so far we have been trying but we realised we are making a mistake of leaving the core mathematics, which is mathematics up to "O" level. Normally our students have got areas of difficulty which they normally face when they go for pedagogical internship. They need to know this to enhance their confidence.

Lecturer 4 and the rest of other lecturers in this research concurred that there was a need to improve to include 'Ordinary' level content in the college mathematics curriculum in order to enhance PSTs' skills of teaching and boost their confidence to present a lesson to learners. The lecturers' views reflected that their college mathematics syllabus did not adequately address what the mathematics PSTs were expected to teach in schools.

\section{Discussion}

This research was carried out on the premise that there is a link between learning to teach and PSTs' expectations. There is a general consensus that PSTs' expectations of teaching are sometimes absolutely divorced from reality during PI (Sag, 2014; Hamaidi et al., 2014). These discrepancies between PSTs expectations and reality have been documented differently by various scholars. This research therefore augmented previous studies by presenting data on the relationship between college PSTs' expectations about teaching mathematics and their actual experiences during PI in Zimbabwe. This adds the usual missing context of a developing country in the academic research milieu.

To answer the 2 research questions, the findings, as reflected in Tables 1 and 2, show that the PSTs' expectations before PI were closely related to their experiences in the classroom. According to Peressini et al. (2004), pre-existing expectations may be preserved if they are consistent with the demands of teaching. In contrast with the findings, the studies of researchers such as Delamarter (2015), Pourdavood (2017) and Wall (2016), however have shown the dissonance that exists between PSTs' expectations and classroom experiences in the field. The issue of PSTs' expectations of teaching mathematics being parallel with their experiences in the classroom may raise a possible ramification on the result. This is because, if PSTs have a set of expectations about teaching and learning and, if these are not perturbed, then they are going to miss opportunities to learn how to teach. To be specific, if a student teacher thinks she/ he is good (expectations) but is unable to identify where she/he is not doing so well, it will be difficult for one to improve. It is therefore essential that teacher education bears the burden to challenge PSTs' preconceptions about teaching (Naylor et al., 2015). This role assists PSTs to have a positive change regarding teaching (Sheridan, 2016) otherwise learning to teach is stifled 
if their expectations align with the class experiences. The perceptions of the lived experiences (Table 1) of PSTs creates an inference that the PSTs may not be the best judges of their performance. For this reason, the self-evaluation that PSTs gave themselves in questionnaires 1 and 2 could have influenced some of them to resist assistance during mentorship. This implies that the PSTs' views and/or expectations about their performance can determine what they learn or do not learn during learning to teach (Naylor et al., 2015).

The similarity between the PSTs expectations and experiences could also be due to the fact that this part of the survey was based on the PSTs' perceptions of their experiences (no lessons were observed), and might not necessarily mean it was happening on the ground. However, Tables 1 and 2 are based on a mixture of relational and instructional practices. The subsequent Table 3 demonstrates the results of the relationship between expectations and experiences of instructional practices only, which are the focus of this research. The results of Table 3 and Figure 1 show that there is a mismatch between PSTs' instructional expectations and experiences. The findings confirm Tarman's (2012) observations that PSTs sometimes ascertain that what they anticipate about teaching is dissimilar to their empirical experiences in the field. The apparent contradiction between the PSTs' perceptions of their practices and the views of their mentors and college educators could also be evidence of the discord that existed between PSTs' expectations before and experiences during PI (Table 5). This result confirms Pourdavood's (2017) assertion of the discrepancies between PSTs' expectations and reality in the classroom.

By and large, when the PSTs were asked to explain their views prior to PI and the manner in which their perceptions had changed during PI, their responses revealed that the PSTs' prior expectations of easily teaching mathematics were high. This was confirmed by the mentors' comments which provided indications on the need for effective PSTs' content delivery methods in the classroom. Failure to effectively teach a lesson could defeat their expectations in the field. PSTs' supposedly distorted frame of mind about teaching and learning mathematics could have a bearing on the rift between expectations and reality of teaching mathematics. Some of the mythical expectations, according to Eisenhardt et al. (2012), impose an obligation on teacher educators to interrogate the teaching methodologies of PSTs and assist them to develop appropriate practices with regards to mathematics teaching. The significance of PCK during internship was emphasised by Shulman (1986) in his treatise of the need to integrate content and pedagogy in the classroom.

This research also found that failure to include high school mathematics in the mathematics teacher education syllabus may defeat the PSTs' expectations to deliver content during PI. In the same vein, Hine (2015) contended that excellent mathematics teachers should have a sound and lucid knowledge of mathematics that is suitable to the level of students they will teach. Without sound mathematics content, pedagogical processes are of little benefit, Hine (2015) wrote. This implies that educators must apply and teach mathematics addressed in schools. It is understandable that there could be concepts which PSTs may have failed to internalise at "Ordinary" level. Such concepts ought to be attended to and spruced up for PSTs, prior to teaching and standing in front of their classes. This could be the reason why Stokking et al. (2003) posited that the level of PI difficulties is dependent on the training PSTs acquired in college or university. The discrepancy between what the PSTs learn in college and what they teach in the classroom may hence contribute to reality shock. This discord between expectations and experiences points out to the fact that effective preparation for PI in colleges is one critical factor in the overall success of PSTs. 
Chipo MAKAMURE. Pre-service teachers' prior expectations and their actual experiences of teaching mathematics during pedagogical internship in Zimbabwe

PROBLEMS

OF EDUCATION

IN THE $21^{\text {st }}$ CENTURY

Vol. 78 , No. 6, 2020

996

\section{Conclusions and Recommendations}

This research applied a mixed methods design by using a sample of PSTs, school-based mentors and teacher education lecturers to explore the relationship between mathematics PSTs expectations prior to PI and their actual practices in the field. The following were the vital findings of the research: 1) There is indeed a conflict between the PSTs' expectations about teaching mathematics and their actual experiences in the field in Zimbabwe. Some PSTs were found to have unrealistic expectations regarding teaching mathematics before field placement. For example, some PSTs, in contrast to their expectations, had difficulties inculcating the skills that they learnt in college into their teaching (Figure 1). 2) It was also established that some of the PSTs' classroom practices are a reflection of their expectations, hence determining their opportunities to learn to teach the subject. Interviews with the PSTs illustrated that their initial practices in the first days on PI were influenced by prior beliefs about teaching. However, this presented some challenges in their classroom work.

This research therefore recommends that teacher training institutions, as an initial step to PSTs' professional preparation, ought to investigate PSTs' beliefs and expectations on teaching mathematics prior to pedagogical internship so as to refocus their perceptions. Teacher training institutions may, for example, sharpen their focus on organising programmes with field practices before PSTs transition to PI so that they are equipped with teaching skills and ready to face classroom challenges that may otherwise take place as a shock during PI. It is also recommended that both teachers' college and school mathematics curricula proffer similar topics in order to reduce the gap between what PSTs learn in college and what they teach in the field.

\section{Limitations}

There is one possible limitation in this study that can be addressed in future research. The results of this study were based on the participants' perceptions only through questionnaires and interviews. It is likely that participants, pre-service teachers in particular, may not be the best judges of their own performance. Though their views were supported or refuted by their educators, the findings could be improved by embracing lesson observations of PSTs during internship in addition to the questionnaires and interviews, so as to establish their actual experiences of teaching. Such an empirical approach would give results that are based on what is happening on the ground rather than entirely depending on participants' understanding of events only.

\section{Acknowledgement}

This paper is part of a PhD thesis: Makamure, C. (2016). Learning to teach secondary school mathematics from practice: An exploration of the Zimbabwean pre-service teachers' year-long field experiences. University of the Free State, South Africa. http://scholar.ufs. ac.za:8080/xmlui/bitstream/handle/11660/5402/MakamureC.pdf?...1...

\section{References}

Barahona, M. (2014). Pre-service teachers' beliefs in the activity of learning to teach English in the Chilean context. Cultural Historical Psychology, 10(2), 116-122. https://psyjournals.ru/en/kip/2014/ n2/70079.shtml

Briley, J. S. (2012). The relationships among mathematics teaching efficacy, mathematics self-efficacy, and mathematical beliefs for elementary pre-service teachers. Issues in the Undergraduate Mathematics Preparation of School Teachers ((IUMPST)): The Journal, 5, 1-13 (Teacher Attributes), http://www.k-12prep.math.ttu.edu/journal/5.attributes/briley01/article.pdf 
Chipo MAKAMURE. Pre-service teachers' prior expectations and their actual experiences of teaching mathematics during pedagogical internship in Zimbabwe

Clark-Goff, K., \& Eslami, Z. (2016). Exploring change in preservice teachers' beliefs about English language learning and teaching. Iranian Journal of Language Teaching Research, 4(3), 21-36. https://files.eric.ed.gov/fulltext/EJ1127318.pdf

Cole, A. L., \& Knowles, J. G. (1993). Shattered images: Understanding expectations and realities of field experiences. Teaching and Teacher Education, 9(5-6), 457-471. https://doi.org/10.1016/0742-051X(93)90030-K

Creswell, J. W. (2014). Research design. Qualitative, quantitative and mixed methods approaches $\left(4^{\text {th }}\right.$ ed.). Sage Publication.

De Neve, D., Devos, G., \& Tuytens, M. (2015). The importance of job resources and self-efficacy for beginning teachers' professional learning in differentiated instruction. Teaching and Teacher Education, 47, 30-41. https://doi.org/10.1016/j.tate.2014.12.003

Debreli, E. (2016). Pre-service teachers' belief change and practical knowledge development during the course of practicum. Journal of Education and Training Studies, 4(7), 37-46. https://doi.org/10.11114/jets.v4i7.1513

Delamarter, J. (2015). Avoiding practice shock: Using teacher movies to realign pre-service teachers' expectations of teaching. Australian Journal of Teacher Education, 40(2), 1-14. https://doi.org/10.14221/ajte.2015v40n2.1

Doyran, F. (2012). Research on teacher education and training. Institute for Education and Research.

Du Toit-Brits, C., \& Nel, P. (2016). The influence of teachers' expectations on mathematics learners' motivation towards mathematics. In Kriek, J. (Ed). Towards effective teaching and meaningful learning in mathematics, science and technology (pp. 80-89). Unisa Press. http://hdl.handle. net $/ 10500 / 22850$.

Eisenhardt, S., Besnoy, K., \& Steele,E.(2012). Creating dissonance in pre-service teachers'field experiences. SRATE Journal, 21(1), 1-10. http://srate.org/JournalEditions/211/1BesnoySteeleEisenhardt.pdf

Feiman-Nemser, S. (2001). From preparation to practice: Designing a continuum to strengthen and sustain teaching. Teachers' College Record, 103(6), 1013-1055. https://eric.ed.gov/?id= EJ640144

Frydaki, E., \& Mamoura, M. (2011). How can practicum experiences transform pre-service teachers' knowledge about teaching and learning? The International Journal of the Humanities, 9(1), 225236. https://doi.org/10.18848/1447-9508/CGP/v09i01/43120

Grouws, D. A., Howald, C. L., \& Colangelon, N. (1996). Students' conceptions of mathematics: A comparison of mathematically talented students and typical high school algebra students. American Educational Research Association.

Haciomeroglu, G. (2013). Mathematics anxiety and mathematical beliefs: What is the relationship in elementary pre-service teachers? Issues in the Undergraduate Mathematics Preparation of School Teachers ((IUMPST)): The Journal, 5, 1-9 (Teacher Attributes. http://www.k-2prep.math.ttu.edu/ journal/5.attributes/haciomeroglu02/article.pdf

Hamaidi, D., Al-Shara, I., Arouri, Y. \& Abu Awwad, F. (2014). Student teachers' perspectives of practicum practices and challenges. European Scientific Journal, 10(13), 191-214. http://dx.doi.org/10.14221/ajte.2015v40n11.7

Hine, G. S. C. (2015). Strengthening pre-service teachers' mathematical content knowledge. Journal of University Teaching \& Learning Practice, 12(4), 1-14. http://ro.uow.edu.au/jutlp/vol12/iss4/5.

Incecay, G. (2011). Effects of learning beliefs of pre-service teachers at an English as a foreign language certificate program on their practice teaching. Turkish OnLine Journal of Qualitative Inquiry, 2(4), 29-38. https://eric.ed.gov/?id= ED537778

Kahn, L. G., Lindstrom, L., \& Murray, C. (2014). Factors contributing to preservice teachers' beliefs about diversity. Teacher Education Quarterly, 41(4), 53-70. http://files.eric.ed.gov/fulltext/ EJ1090541.pdf

Stokking, K., Leenders, F., De Jong, J., \& Van Tartwijk, J. (2003). From student to teacher: Reducing practice shock and early dropout in the teaching profession. European Journal of Teacher Education, 26(3), 329-350. https://doi.org/10.1080/0261976032000128175

Kline, P. (1999). The handbook of psychological testing. Routledge.

Lee, J., Zhang, Z., Song, H., \& Huang, X. (2013). Effects of epistemological and pedagogical beliefs on the instructional practices of teachers: A Chinese perspective. Australian Journal of Teacher Education, 38(12), 120-146. https://dx.doi.org/10.14221/ajte.2013v38n12.3 
Chipo MAKAMURE. Pre-service teachers' prior expectations and their actual experiences of teaching mathematics during pedagogical internship in Zimbabwe

PROBLEMS

OF EDUCATION

IN THE $21^{\text {st }}$ CENTURY Vol. 78, No. 6, 2020

998

Leikin, R., \& Levav-Waynberg, A. (2009). Development of teachers' conceptions through learning and teaching: Meaning and potential of multiple-solutions tasks. Canadian Journal of Science, Mathematics and Technology Education, 9(4), 203-223. https://doi. org/10.1080/14926150903314305

Lo, W. Y., \& Anderson, J. (2010). Beyond the curriculum: The mathematics beliefs of pre-service primary teachers in Hong Kong. In L. Sparrow, B. Kissane \& C. Hurst (Eds.), Shaping the future of mathematics education, Proceedings of the 33rd annual conference of the mathematics education Research Group of Australasia, (pp. 657-664). MERGA. https://eric.ed.gov/?id=ED521024

Makamure, C. (2016). Learning to teach secondary school mathematics from practice: An exploration of the Zimbabwean pre-service teachers' year-long field experiences. University of the Free State, South Africa. http://scholar.ufs.ac.za:8080/xmlui/bitstream/handle/11660/5402/Author.pdf?...1...

McDiarmid, W., \& Ball, D. L. (1998). The teacher education and learning to teach study (TELT): An occasion for developing a conception of teacher knowledge. College of Education, Michigan State University.

Nahal, S. P. (2009). Exploring disparities between teachers' expectations and the realities of the education profession. University of Phoenix.

Naylor, D. A., Campbell-Evans, G., \& Maloney, C. (2015). Learning to teach: What do pre-service teachers report? Australian journal of Teacher Education, 40(11), 119-136. http://dx.doi.org/10.14221/ ajte. $2015 \mathrm{v} 40 \mathrm{n} 11.7$

Osborne, J. W., \& Overbay, A. (2004). The power of outliers (and why researchers should ALWAYS check for them). Practical Assessment, Research \& Evaluation Journal, 9(6), 1-8. https://doi.org/10.7275/qf69-7k43

Peressini, D., Borko, H., Romagnano, L., Knuth, E., \& Willis, C. (2004). A conceptual framework for learning to teach secondary mathematics: A situative perspective. Educational Studies in Mathematics, 56(1), 67-96. https://doi.org/10.1023/B:EDUC.0000028398.80108.87.

Pourdavood, R. (2017). Pre-Service elementary teachers' experiences, expectations, beliefs, and attitudes toward mathematics teaching and learning. International Journal of Learning, Teaching and Educational Research, 16(11), 1-27. https://doi.org/10.26803/ijlter.16.11.1.

Purnomo, Y. W., Suryadi, D., \& Darwis, S. (2016). Examining pre-service elementary school teacher beliefs and instructional practices in mathematics class. International Electronic Journal of Elementary Education, 8(4), 629-642. http://files.eric.ed.gov/fulltext/ EJ1109870.pdf

Sag, R. (2014). The course of pre-service teachers' expectations in school practices and the factors affecting their expectations. Creative Education.

Sheafer, V. (2014). Using service learning to teach classic learning theories. Le Tourneau University.

Sheridan, L. (2016). Examining changes in pre-service teachers' beliefs of pedagogy. Australian Journal of Teacher Education, 41(3), 1-20. http://dx.doi.org/10.14221/ajte.2016v41n3.1

Shulman, L. S. (1986). Those who understand: Knowledge growth in teaching. Educational Researcher, 15(2), 4-14. https://doi.org/10.3102/0013189X015002004.

Sivo, S. A., Saunders, C., Chang, Q., \& Jiang, J. J. (2006). How low should you go? Low response rate and the validity of inference in IS questionnaire research. Journal of the Association for Information Systems, 7(6), 351-414. https://doi.org/10.17705/1jais.00093

Tarman, B. (2012). Prospective teachers' beliefs and perceptions about teaching as a profession. Educational Sciences: Theory and Practice, 12(3), 1964-1973. https://files.eric.ed.gov/fulltext/ EJ1000904.pdf

Wall, C. R. G. (2016). From student to teacher: changes in pre-service teacher educational beliefs throughout the learning-to-teach journey. Teacher Development-An International Journal of Teachers' Professional Development, 20(3), 364-379. https://doi.org/10.1080/13664530.2016.11 49509

Weinstein, C. S. (1988). Pre-service teachers' expectations about the first year of teaching. Teaching and Teacher Education, 4(1), 31-40. https://doi.org/10.1016/0742-051X(88)90022-4

White, J. W., \& Chant, R. H. (2014). Challenging idealism: Pre-service teachers' core beliefs before, during, and after an extended field-based experience. Teacher Education Quarterly, 41(2), 7392. https://files.eric.ed.gov/fulltext/EJ1079177.pdf 
Chipo MAKAMURE. Pre-service teachers' prior expectations and their actual experiences of teaching mathematics during pedagogical internship in Zimbabwe

PROBLEMS

OF EDUCATION

IN THE $21^{\text {st }}$ CENTURY

Vol. 78 , No. 6, 2020

Yilmaz, H., \& Sahin, S. (2011). Pre-service teachers' epistemological beliefs and conceptions of teaching. Australian Journal of Teacher Education, 36(1), 73-88. https://doi.org/10.14221/ajte.2011v36n1.6

999

Received: May 08, 2020

Accepted: November 12, 2020

Cite as: Makamure, C. (2020). Pre-service teachers' prior expectations and their actual experiences of teaching mathematics during pedagogical internship in Zimbabwe. Problems of Education in the $21^{\text {st }}$ Century, 78(6), 983-999. https://doi.org/10.33225/pec/20.78.983

Chipo Makamure

PhD, Post-Doctoral Research Fellow, University of South Africa (UNISA), Preller St, Muckleneuk Ridge, Pretoria, 0002, Republic of South Africa.

E-mail: makamc@unisa.ac.za

ORCID: https://orcid.org/0000-0002-4014-8208 